\title{
Efektivitas Model Pembelajaran Team Assisted Individualization terhadap Kemampuan Berpikir Kritis Matematis Peserta Didik SMA
}

\author{
Betri Wendra $^{1 *}$, Nurhayati ${ }^{2}$, Husni El Hilali ${ }^{3}$ \\ ${ }^{1,3}$ UIN Sulthan Thaha Saifuddin Jambi, ${ }^{2}$ Universitas Jambi \\ *betri.wendra@uinjambi.ac.id
}

\begin{abstract}
ABSTRAK
Penelitian ini bertujuan untuk membahas pengaruh penerapan model pembelajaran Team Assisted Individualization terhadap peningkatan kemampuan berpikir kritis matematis peserta didik Sekolah Menengah Atas Negeri 11 Muaro Jambi pada pokok bahasan Trigonometri. Penelitian ini merupakan penelitian kuantitatif dengan desain Pretest-Postest Control Group Design. Teknik pengambilan sampel menggunakan Simple Random Sampling dengan jumlah sampel 15 peserta didik di kelas X MIA 2 sebagai kelas eksperimen dan 15 peserta didik di kelas X MIA 1 sebagai kelas kontrol. Teknik pengumpulan data dilakukan dengan teknik tes dengan tes esai berjumlah 4 soal. Analisis pada penelitian ini menggunakan uji $t_{\text {test }}$ dan uji korelasi phi. Dari uji $t_{\text {test }}$ pada taraf signifikansi $5 \%$ dan $1 \%$ diperoleh $2,05<4,8339>2,76$ dan dari hasil uji korelasi phi pada taraf signifikansi $5 \%$ dan $1 \%$ diperoleh $0,361<0,7399>0,463$. Artinya bahwa penerapan model pembelajaran Team Assisted Individualization berpengaruh secara signifikan terhadapan kemampuan berpikir kritis matematis peserta didik.

Kata kunci: pembelajaran Team Asissted Individualization, kemampuan berpikir kritis matematis.
\end{abstract}

\section{ABSTRACT}

This study discussed about effect of Team Assisted Individualization method on students mathematics critical thinking skill at senior high school 11 Muaro Jambi on the subject Trigonometry. This study was designed a quantitative research with pretest posttest control group design. The technique of collecting data used Simple Random Sampling the number of sample 15 students. Of the first grade MIA 2 as experiment class and 15 students at first grade MIA 1 as control class. The collecting of data finished by technique of test with esai test amounted to 4 questions. The analysis in this study used test and phi correlation test. From the test at 5\% and 1\% significance level obtained 2,05<4,8339>2,76 and from the results of the correlation test phi at significance level of $5 \%$ and $1 \%$ obtained 0,361 $<0,7399>0,463$. This means that the implementation of the learning model of Team Assisted Individualization significantly influences the critical thinking ability of the learners.

Keywords: Team Assisted Individualization method, mathematics critical thinking ability. 


\section{PENDAHULUAN}

Pembelajaran matematika adalah suatu proses belajar mengajar yang dibangun oleh guru untuk mengembangkan kreativitas berpikir peserta didik yang dapat meningkatkan kemampuan berpikir peserta didik, serta meningkatkan kemampuan mengkonstruksi pengetahuan baru sebagai upaya meningkatkan penguasaan yang baik terhadap materi matematika (Susanto, 2013; Martiana, 2015; Sulistyani, 2012). Salah satu tujuan pembelajaran matematika yaitu untuk meningkatkan kemampuan berpikir kritis (Syutharidho \& Rakhmawati, 2015; Aziz, Ahyan, \& Fauzi,2016; Ismaimuza, 2010; Yulianti, Zulkardi, \& Ilma, 2010; Sutandi \& Mahmudi, 2015). Kemampuan berpikir kritis merupakan keterampilan yang efektif untuk membantu seseorang membuat, mengevaluasi dan menggunakan keputusan tentang apa yang diyakini dan dapat dikerjakan. Berpikir kritis dapat dipahami sebagai kegiatan menganalisis ide atau gagasan ke arah yang lebih spesifik, membedakannya secara tajam, memilih, mengidentifikasi, mengkaji, dan mengembangkannya ke arah yang lebih sempurna (Fisher, 2009; Rusman, 2013; Shoimin, 2016; Susanto, 2013; Suprijono, 2015). Jadi kemampuan berpikir kritis adalah kemampuan seseorang untuk dapat menyikapi suatu persoalan dengan tepat.

Untuk meningkatkan keterampilan berpikir peserta didik, pengajar hendaknya membuka kesempatan pada mereka untuk mengembangkan kemampuan berpikir kritis dan kreatif secara teratur. Mereka dipancing untuk memeriksa jawaban dan membahasnya merupakan salah satu jalan ke arah itu. Sehingga dalam hal ini dibutuhkan suatu model pembelajaran yang tepat dan sesuai. Model adalah suatu rencana atau pola yang digunakan dalam menyusun kurikulum, mengatur materi peserta didik, dan memberi petunjuk kepada pengajar di kelas dalam setting pengajaran atau setting lainnya (Hamzah \& Muhlisraini, 2014; Yamin, 2013).

Observasi awal pada penelitian ini menunjukkan bahwa model pembelajaran yang diterapkan kurang efektif untuk meningkatkan kemampuan berpikir kritis peserta didik. Bahkan, sebagian guru tidak pernah mengevaluasi model pembelajaran yang sudah diterapkan, padahal model pembelajaran sangat penting untuk mencapai tujuan pembelajaran. Salah satu model yang dapat dijadikan alternatif dalam meningkatkan kemampuan berpikir kritis peserta didik yaitu model pembelajaran Team Assisted Individualization.

Team Assisted Individualization memiliki dasar pemikiran untuk mengadaptasi pengajaran terhadap perbedaan individual berkaitan dengan kemampuan maupun pencapaian prestasi peserta didik (Slavin, 2015; Sulistyani, 2012). Unsur dalam Team Assisted Individualization yang diduga mampu meningkatkan kemampuan berpikir kritis peserta didik adalah pada saat pembelajaran individu, peserta didik dilatih untuk mengenal dan memecahkan masalah sendiri dan pada saat pembelajaran berkelompok, peserta didik saling tukar pendapat untuk menyelesaikan masalah. Peserta didik bertanggung jawab atas semua pengecekan jawaban anggota kelompoknya. Pada saat pengecekan jawaban peserta didik dilatih untuk menganalisis jawaban anggota kelompoknya dan menarik kesimpulan yang benar dan salah.

Selain itu, model pembelajaran Team Assisted Individualization pada hakekatnya melibatkan tugas yang memungkinkan peserta didik saling membantu dan mendukung dalam menyelesaikan tugas sehingga peserta didik mempunyai banyak kesempatan untuk mengolah informasi dan meningkatkan keterampilan berkomunikasi. Dalam proses pembelajaran, peserta didik dikelompokkan dalam suatu kelompok kecil yang heterogen dalam hal kemampuan 
akademis, jenis kelamin, sosial ekonomi. Kesulitan pemahaman materi yang tidak dapat dipecahkan sendiri dapat dipecahkan secara bersama-sama dengan anggota kelompoknya serta bimbingan guru (Gazali, 2015).

Beberapa penelitian menggunakan model pembelajaran Team Assisted Individualization sebelumnya pernah dilakukan oleh beberapa peneliti lain seperti: (1) Gazali (2015) tentang eksperimentasi model pembelajaran Team Assisted Individualization ditinjau dari kemandirian belajar, hasil penelitiannya menunjukkan bahwa pembelajaran kooperatif dapat meningkatkan hasil belajar siswa dan model TAI Guide Note Taking lebih baik dari model konvesional. (2) Farnika, Ikhsan, dan \& Sofyan (2015) tentang peningkatan kemampuan pemahaman dan pemecahan masalah matematis siswa Sekolah Menengah Atas dengan model pembelajaran kooperatif tipe Team Assisted Individualization, hasil penelitiannya menunjukkan bahwa peningkatan kemampuan pemahaman dan pemecahan masalah matematis siswa yang memperoleh pembelajaran dengan menggunakan model kooperatif tipe TAI lebih baik daripada siswa yang memperoleh pembelajaran konvensional ditinjau berdasarkan keseluruhan siswa, dan level siswa (tinggi, sedang dan rendah). (3) Purwa (2017) tentang implementasi model pembelajaran STAD dan TAI ditinjau dari kemampuan spasial siswa, hasil penelitiannya menunjukkan bahwa penerapan model pembelajaran TAI memberikan hasil prestasi belajar yang lebih baik dari model pembelajaran langsung. (4) Setianingsih (2016) tentang keefektifan Problem Solving dan Guided Inquiry dalam setting TAI ditinjau dari prestasi belajar, kemampuan berpikir kritis, dan kedisiplinan diri, hasil penelitiannya menunjukkan bahwa pendekatan pembelajaran Problem Solving setting TAI dan Guided Inquiry setting TAI efektif ditinjau dari prestasi belajar, kemampuan berpikir kritis, dan kedisiplinan diri. (5) Dwi \& Maman (2015) tentang keefektifan pembelajaran Jigsaw dan TAI ditinjau dari kemampuan penalaran dan sikap belajar matematika siswa, hasil penelitiannya menunjukkan bahwa pembelajaran matematika dengan model pembelajaran kooperatif tipe Jigsaw dan TAI masingmasing efektif ditinjau dari kemampuan penalaran dan sikap belajar matematika siswa.

Sebagai bentuk pengembangan dari penelitian yang telah dilakukan oleh para ahli di atas, penelitian ini juga menerapkan model pembelajaran Team Assisted Individualization. Namun yang membedakan penelitian ini dengan penelitian-penelitian sebelumnya adalah fokus kemampuan peserta didik yang diteliti (kemampuan berpikir kritis matematis) setelah diterapkan murni satu model pembelajaran (Team Assisted Individualization). Adapun tujuan dari penelitian ini yaitu untuk mengetahui adakah penerapan model pembelajaran Team Assisted Individualization di kelas eksperimen berpengaruh signifikan terhadap kemampuan berpikir kritis matematis peserta didik, dengan cara membandingkan dengan model pembelajaran Student Teams Achievement Divisions yang diterapkan di kelas kontrol.

\section{METODE}

Penelitian ini merupakan penelitian kuantitatif dengan desain penelitian yang digunakan yaitu Pretest-Posttest Control Group Design (Sugiyono, 2009; Sudjiono, 2015). Dalam penerapannya, responden (peserta didik) dibagi menjadi dua kelas, yaitu: (1) Kelas Eksperimen yang diterapkan model pembelajaran Team Assisted Individualization dan (2) Kelas Kontrol yang diterapkan model pembelajaran Student Teams Achievement Divisions. Sebelum penerapan model pembelajaran dilakukan, kepada responden dari kelas eksperimen dan kelas kontrol 
diberikan Pretest untuk melihat kemampuan awal. Proses pembelajaran dilakukan selama $2 \times$ 45 menit setiap pertemuan. Penelitian ini dilakukan selama 4 kali pertemuan. Adapun materi yang dibahas adalah Trigonometri. Trigonometri merupakan salah satu pokok bahasan dalam matematika yang menuntut kemampuan analisis dan berpikir kritis matematis yang sangat baik untuk memahaminya.

Setelah rangkaian proses penerapan model pembelajaran dilakukan, responden diberikan Posttest untuk melihat hasil dari penerapan masing-masing model pembelajaran untuk kemudian dibandingkan. Dalam penelitian ini diasumsikan bahwa kemampuan berpikir kritis matematis peserta didik dari kelas eksperimen lebih baik daripada kelas kontrol.

Penelitian ini dilakukan di SMA Negeri 11 Muaro Jambi dalam rentang tanggal 27 Februari sampai dengan 27 April 2018. Populasi dalam penelitian ini merupakan peserta didik kelas X jurusan Matematika dan Ilmu Pengetahuan Alam (MIA) yang terdiri dari 2 kelas. Adapun deskripsi data subjek penelitian dapat dilihat pada Tabel 1 berikut.

Tabel 1. Jumlah Peserta Didik Kelas X Jurusan MIA SMA Negeri 11 Muaro Jambi

\begin{tabular}{ccccc}
\hline No. & Kelas & Laki-laki & Perempuan & Jumlah \\
\hline 1 & X MIA 1 & 5 & 16 & 21 \\
2 & X MIA 2 & 6 & 17 & 23 \\
& Jumlah & $\mathbf{1 1}$ & $\mathbf{3 3}$ & $\mathbf{4 4}$ \\
\hline
\end{tabular}

Pengambilan sampel dilakukan dengan cara simple random sampling. Sampel berjumlah 15 peserta didik pada kelas MIA 2 sebagai kelompok eksperimen dan 15 peserta didik pada kelas MIA 1 sebagai kelompok kontrol. Dengan total sampel keseluruhan 30 peserta didik. Terhadap populasi dan sampel dilakukan uji normalitas menggunakan Uji Liliefors dan uji homogenitas menggunakan uji beda varians. Dari hasil uji normalitas terhadap populasi pada Tabel 2 diperoleh bahwa $L_{\text {hitung }}<L_{\text {tabel }}$, dengan kata lain populasi berdistribusi normal.

Tabel 2. Hasil Uji Normalitas Populasi

\begin{tabular}{ccccc}
\hline Kelas & Jumlah Peserta Didik & $L_{\text {hitung }}$ & $L_{\text {tabel }}$ & Keterangan \\
\hline X MIA 1 & 21 & 0,15067 & 0,1866 & Normal \\
X MIA 2 & 22 & 0,13636 & 0,1830 & Normal \\
\hline
\end{tabular}

Hasil uji homogenitas terhadap populasi pada Tabel 3 diperoleh bahwa $f_{\text {hitung }}<f_{\text {tabel }}$, dengan kata lain populasi bervarian homogen. Selanjutnya dilakukan pengambilan sampel, yang terdiri dari 15 peserta didik kelas X MIA 2 sebagai kelas eksperimen dan 15 peserta didik kelas X MIA 1 sebagai kelas kontrol.

Tabel 3. Hasil Uji Homogenitas Populasi

\begin{tabular}{ccccc}
\hline Varians Terbesar & Varians Terkecil & $f_{\text {hitung }}$ & $f_{\text {tabel }}$ & Keterangan \\
& & & \\
\hline 125,4714 & 121,1198 & 1,038 & 2,090 & Homogen \\
\hline
\end{tabular}

Uji normalitas dan uji homogenitas terhadap sampel dilakukan terhadap data hasil pretest dan post-test kemampuan berpikir kristis matematis peserta didik kelas eksperimen dan 
kontrol. Hasil uji normalitas terhadap sampel pada Tabel 4 diperoleh bahwa $L_{\text {hitung }}<L_{\text {tabel }}$, dengan kata lain sampel berdistribusi normal.

Tabel 4. Hasil Uji Normalitas Sampel

\begin{tabular}{ccccccc}
\hline \multirow{2}{*}{ Kelas } & \multirow{2}{*}{ Jumlah Peserta Didik } & \multicolumn{2}{c}{ Pre-Test } & \multicolumn{2}{c}{ Post-Test } & \multirow{2}{*}{ Keterangan } \\
\cline { 3 - 6 } & & $L_{\text {hitung }}$ & $L_{\text {tabel }}$ & $L_{\text {hitung }}$ & $L_{\text {tabel }}$ & \\
\hline X MIA 1 & 15 & 0,119 & 0,220 & 0,1995 & 0,220 & Normal \\
X MIA 2 & 15 & 0,214 & 0,220 & 0,1961 & 0,220 & Normal \\
\hline
\end{tabular}

Hasil uji homogenitas terhadap sampel pada Tabel 5 diperoleh bahwa $f_{\text {hitung }}<f_{\text {tabel }}$, dengan kata lain sampel bervarian homogen.

Tabel 5. Hasil Uji Homogenitas Sampel

\begin{tabular}{cccccc}
\hline Data & Varians Terbesar & Varians Terkecil & $f_{\text {hitung }}$ & $f_{\text {tabel }}$ & Keterangan \\
\hline Pre-Test & 485,9997 & 411,5543 & 1,1809 & 2,48 & Homogen \\
Post-Test & 200,6671 & 89,332 & 2,25 & 2,48 & Homogen \\
\hline
\end{tabular}

Teknik pengumpulan data pada penelitian ini menggunakan instrumen berupa Tes Esai yang terdiri dari empat soal yang telah divalidasi oleh tim ahli dari dua orang dosen dan satu orang guru matematika yang mengajar di kelas tempat dilakukan penelitian. Validasi terhadap instrumen Tes Esai diperoleh setelah beberapa perbaikan, dengan rata-rata penilaian dari validator adalah Sangat Baik. Setelah pre-test dan post-test, dilakukan analisis secara eksternal dan internal. Secara internal dilakukan perhitungan selisih antara pre-test kelas eksperimen dan post-test kelas eksperimen dan perhitungan selisih antara pre-test kelas kontrol dan post-test kelas kontrol. Analisis eksternal dengan menghitung selisih rata-rata antara pre-test kelas eksperimen dan kelas kontrol dan perhitungan selisih rata-rata antara post-test kelas eksperimen dan kelas kontrol. Adapun teknik analisis data menggunakan $t_{\text {test }}$ dan uji korelasi phi (Sudjana, 2005; Riduwan, 2013; Salman \& Winfrey, 2020).

\section{HASIL DAN PEMBAHASAN}

Data utama dalam penelitian ini merupakan hasil Pre-test dan Post-test peserta didik dari kelas eksperimen dan kelas kontrol yang masing-masing terdiri atas 15 peserta didik. Soal Pretest dan Post-test yang diberikan berupa Tes Esai yang dirancang untuk mengukur kemampuan berpikir kritis matematis peserta didik.

Uji normalitas dan homogenitas dilakukan terhadap populasi, hasil Pre-test, dan hasil Post-test. Lebih lanjut pada hasil Post-test, untuk melihat signifikan atau tidaknya penerapan model pembelajaran Team Assisted Individualization dan Student Team Achievemment Division terhadap kemampuan berpikir kritis matematis peserta didik akan diukur dengan menggunakan uji $t$ dan korelasi phi. 
Tabel 6. Hasil Tes Kemampuan Berpikir Kritis Matematis Responden (Peserta Didik)

\begin{tabular}{cccccc}
\hline \multirow{2}{*}{ No. } & \multirow{2}{*}{ Ukuran Penetapan } & \multicolumn{2}{c}{ Pre-test } & \multicolumn{2}{c}{ Post-test } \\
\cline { 3 - 6 } & Kelas Ekspreimen & Kelas Kontrol & Kelas Ekspreimen & Kelas Kontrol \\
\hline 1 & Skor Tertinggi & 70 & 80 & 100 & 95 \\
2 & Skor Terendah & 20 & 20 & 70 & 50 \\
3 & Rentangan & 50 & 60 & 30 & 45 \\
4 & Mean & 51 & 48 & 88 & 66 \\
5 & Median & 60 & 50 & 80 & 65 \\
6 & Modus & 65 & 80 & 70 & 50 \\
7 & Standar Deviasi & 18,2998 & 22,0454 & 9,4516 & 14,1657 \\
8 & Standar Eror & 4,8909 & 5,8919 & 2,5260 & 3,7859 \\
\hline
\end{tabular}

Berdasarkan Tabel 2, selisih nilai rata-rata skor pre-test pada kelas eksperimen dan kontrol sebesar 3 sedangkan pada posttest sebesar 22. Selisih nilai rata-rata pre-test dan posttest kelas eksperimen sebesar 37 sedangkan selisih nilai rata-rata pre-test dan post-test pada kelas kontrol sebesar 18. Maka skor kemampuan berpikir kritis matematis peserta didik kelas eksperimen lebih tinggi dibandingkan dengan kelas kontrol. Secara umum dapat disimpulkan bahwa kemampuan berpikir kritis matematis peserta didik yang menerapkan model pembelajaran Team Asissted Individualization lebih baik dari pada yang menerapkan model pembelajaran Student Team Achievemment Division.

Analisis lebih lanjut dilakukan uji hipotesis. Karena $t_{0}$ yang telah diperoleh sebesar 4,8339 sedangkan $t_{\text {tabel }}=2,05$ untuk taraf signifikansi $5 \%$ dan $t_{\text {tabel }}=2,76$ untuk taraf signifikansi $1 \%$, maka $t_{0}$ lebih besar dari $t_{\text {tabel }}$ pada kedua taraf signifikansi tersebut atau 2,05 $<4,8339>2,76$. Dengan demikian maka hipotesis nihil ditolak, artinya kedua nilai tes kelas eksperimen dan kelas kontrol memiliki perbedaan mean yang signifikan.

Untuk melihat berapa besar signifikansi pengaruh penerapan model pembelajaran Team Assisted Individualization terhadap kemampuan berpikir kritis matematis peserta didik digunakan uji korelasi phi. Karena $\varphi$ yang diperoleh melalui perhitungan $(\varphi=0,7399)$ lebih besar dari pada $r_{\text {tabel }}$ pada taraf signifikansi $5 \%$ dan $1 \%$ atau $0,361<0,7399>0,463$, maka $H_{0}$ ditolak. Berarti terdapat pengaruh yang signifikan penerapan model pembelajaran Team Asissted Individualization terhadap kemampuan berpikir kritis matematis peserta didik. Sehingga dapat disimpulkan bahwa kemampuan berpikir kritis matematis peserta didik yang menerapkan model pembelajaran Team Assisted Individualization lebih baik dari pada kemampuan berpikir kritis peserta didik yang menerapakan model pembelajarn Student Teams Achievement Divisions. Hasil ini menunjukkan hasil yang sama dengan penelitian-penelitian sebelumnya, namun novelty dari penelitian ini terletak pada fokus kemampuan peserta didik yang diteliti yaitu kemampuan berpikir kritis matematis hasil dari diterapkan murni satu model pembelajaran yaitu model pembelajaran Team Assisted Individualization.

\section{SIMPULAN}

Penelitian ini bertujuan menganalisis efektivitas penerapan model pembelajaran Team Assisted Individualization terhadap kemampuan berpikir kritis matematis peserta didik di Sekolah Menengah Atas Negeri 11 Muaro Jambi. Adapun kesimpulan dari penelitian ini adalah kemampuan berpikir kritis matematis peserta didik yang menerapkan model pembelajaran 
Team Asissted Individualization lebih baik dari pada kemampuan berpikir kritis matematis peserta didik yang menerapan model pembelajaran Student Teams Achievement Divisions. Hal ini berdasarkan hasil perhitungan uji $t$ yaitu $t_{\text {hitung }}=4,833$ yang lebih tinggi dibandingkan

$t_{\text {tabel }}=2,05$ pada taraf signifikansi $5 \%$ dan $t_{\text {tabel }}=2,76$ pada taraf signifikansi $1 \%$. Selain itu kesimpulan ini juga dipertegas dari hasil perhitungan korelasi phi yaitu $\varphi=0,7399$ yang lebih tinggi daripada $r_{\text {tabel }}=0,361$ pada taraf signifikansi 5\% dan $r_{\text {tabel }}=0,463$ pada taraf signifikansi $1 \%$.

\section{DAFTAR PUSTAKA}

Aziz, A., Ahyan, S., \& Fauzi, L.M. (2016). Implementasi Model Problem Based Learning (PBL) Dalam Meningkatkan Kemampuan Berpikir Kritis Mahasiswa Melalui Lesson Study. Jurnal Elemen, 2(1), 83-91.

Dwi, R.A. \& Maman, A.A. (2015). Keefektifan Pembelajaran Jigsaw dan TAI Ditinjau Dari Kemampuan Penalaran dan Sikap Belajar Matematika Siswa. Jurnal Riset Pendidikan Matematika, 2(2), 235-250.

Farnika, N., Ikhsan, M., \& Sofyan, H. (2015). Peningkatan Kemampuan Pemahaman dan Pemecahan Masalah Matematis Siswa Sekolah Menengah Atas Dengan Model Pembelajaran Kooperatif Tipe Team Assisted Individualization. Jurnal Elemen, 1(2), 144-152.

Fisher, A. (2009). Berpikir Kritis. Jakarta: Erlangga.

Gazali, M. (2015). Eksperimentasi Model Pembelajaran Team Assisted Individualization Ditinjau Dari Kemandirian Belajar. Jurnal Elemen, 1(1), 71-79.

Hamzah, A., \& Muhlisraini (2014). Perencanaan dan Strategi Pembelajaran Matematika. Jakarta: PT Raja Grafindo Persada.

Ismaimuza, D. (2010). Pengaruh Pembelajaran Berbasis Masalah Dengan Strategi Konflik Kognitif Terhadap Kemampuan Berpikir Kritis Matematis dan Sikap Siswa SMP. Jurnal Pendidikan Matematika, 4(1), 1-10.

Martiana, D. (2015). Meningkatkan Kemampuan Berpikir Kritis Matematis Siswa dengan Menggunakan Model Pembelajaran Kooperatif Tipe Team Assisted Individualization (TAI). Skripsi Pendidikan Matematika FITK UIN Syarif Hidayatullah.

Purwa, A.K. (2017). Implementasi Model Pembelajaran Student Teams Achievement Division (STAD) dan Team Assisted Individualization (TAI) Ditinjau Dari Kemampuan Spasial Siswa. Al-Jabar: Jurnal Pendidikan Matematika, 8(2), 135-144.

Salman, T.A. \& Winfrey, B.S. (2020). Student Engagement and Math Teachers Support. Journal on Mathematics Education, 11(2), 167-180.

Setianingsih, H. (2016). Keefektifan Problem Solving dan Guided Inquiry Dalam Setting TAI Ditinjau Dari Prestasi Belajar, Kemampuan Berpikir Kritis, dan Kedisiplinan Diri. Jurnal Riset Pendidikan Matematika, 3(2), 221-233.

Sutandi, T.N. \& Mahmudi, A. (2015). Keefektifan Pembelajaran Berbasis Masalah dan Problem Posing Ditinjau Dari Kemampuan Berpikir Logis dan Kritis. Jurnal Riset Pendidikan Matematika, 2(1), 107-120.

Riduwan (2013). Dasar Dasar Statistika. Bandung: Alfabeta. 
Rusman (2013). Belajar dan Pembelajaran Berbasis Komputer Mengembangkan Profesionalisme Guru Abad 21. Bandung: Alfabeta.

Shoimin, A. (2016). 68 Model Pembelajaran Inovatif dalam Kurikulum 2013. Yogyakarta: ArRuzz Media.

Syutharidho \& Rakhmawati, R.M. (2015). Pengembangan Soal Berpikir Kritis Untuk Siswa SMP Kelas VIII. Al-Jabar: Jurnal Pendidikan Matematika, 6(2), 219-227.

Slavin, R.E. (2015). Cooperative Learning Teori, Riset,dan Praktik. Bandung: Nusa Media.

Sudjana (2005). Metoda Statistika. Bandung: Tarsito.

Sudjiono, A. (2015). Pengantar Statistik Pendidikan. Jakarta : PT Raja Grafindo Persada.

Sugiyono (2009). Metode Penelitian Kuantitatif kualitatif dan R\&D. Bandung: Alfabeta.

Sulistyani, N. (2012). Implementasi Pembelajaran Berbasis Masalah Dipadukan Dengan Pembelajaran Kooperatif Tipe Team Assisted Individualization Untuk Meningkatkan Kemampuan Berpikir Kritis Matematis Pada Peserta Didik SMP Negeri 2 Sentolo Kelas $I X A$. Jurnal Pendidikan Pasca Sarjana UNY.

Suprijono, A. (2015). Cooperative Learning. Yogyakarta: Pustaka Pelajar.

Susanto, A. (2013). Teori Belajar dan Pembelajaran di Sekolah Dasar. Jakarta: Kencana Prenada Media Group.

Yamin, M. (2013). Strategi \& Metode dalam Model Pembelajaran. Jakarta: GP Press Group.

Yulianti, Zulkardi, \& Ilma, R.I.P. (2010). Pengembangan Perangkat Pembelajaran Peluang Berbasis Reciprocal Teaching Untuk Melatih Kemampuan Berpikir Kritis Siswa Kelas XI SMK Negeri 3 Lubuk Linggau. Jurnal Pendidikan Matematika, 4(2), 97-114. 